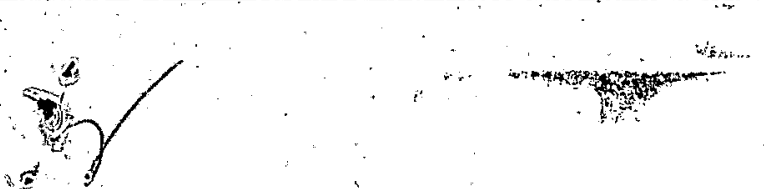

MEXICAN-AMERICAN COOPERATIVE PROGRAM AT THE CERRO PRIETO GEOTHERMAL FIELD

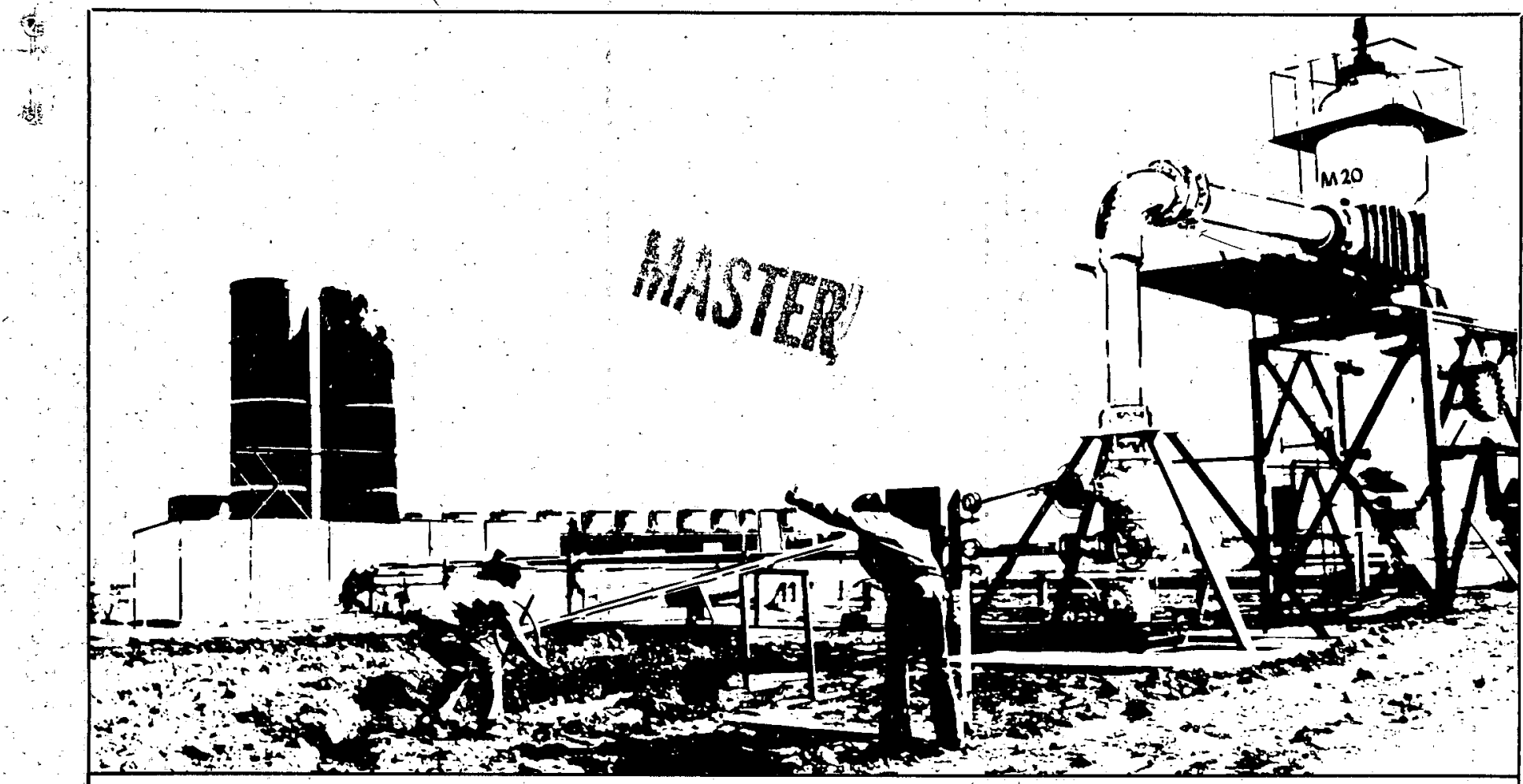

\title{
SIMULATION OF REINJECTION AT CERRO PRIETO USING AN IDEALIZED TWO-RESERVOIR MODEL
}

\author{
C. F. Tsang, D.C. Mangold and M. J. Lippmann
}

FEBRUARY 19.80

\section{COMISION FEDERAL DE ELECTRICIDAD}

A Joint Project of

\section{Mexico}

Coordinadora Ejecutiva de Cerro Prieto

Apdo. Postal No. 3-636

Mexicali, Bja. 'Cfa., México

and P. O. Box 248

Calexico, Ca. 92231
DEPARTMENT OF ENERGY

Division of Geothermal Energy

United States of America

Coordinated by

Lawrence Berkeley Laboratory

Earth Sciences Division

University of California

Berkeley; California 94720

Operating for the U.S. Department of

Energy under Contract W-7405-ENG-48 


\section{DISCLAIMER}

This report was prepared as an account of work sponsored by an agency of the United States Government. Neither the United States Government nor any agency Thereof, nor any of their employees, makes any warranty, express or implied, or assumes any legal liability or responsibility for the accuracy, completeness, or usefulness of any information, apparatus, product, or process disclosed, or represents that its use would not infringe privately owned rights. Reference herein to any specific commercial product, process, or service by trade name, trademark, manufacturer, or otherwise does not necessarily constitute or imply its endorsement, recommendation, or favoring by the United States Government or any agency thereof. The views and opinions of authors expressed herein do not necessarily state or reflect those of the United States Government or any agency thereof. 


\section{DISCLAIMER}

Portions of this document may be illegible in electronic image products. Images are produced from the best available original document. 

Submitted to the Proceedings of the Second

Symposium on the Cerro Prieto Geothermal Field,

Baja California, Mexico, October 17-19, 1979

\section{SIMULATION OF REINJECTION AT CERRO PRIETO \\ USING AN IDEALIZED TWO-RESERVOIR MODEL}

C. F. Tsang, D. C. Mangold, and M. J. Lippmann

Lawrence Berkeley Laboratory

University of California

Berkeley, California 94720

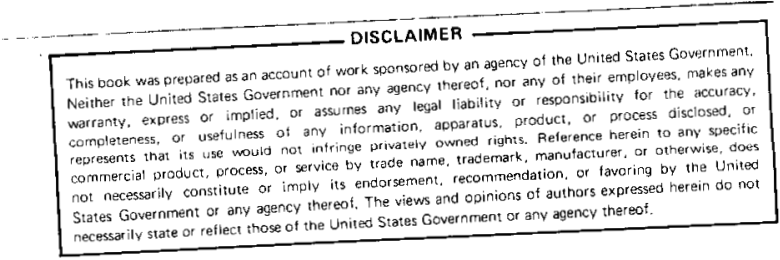




\title{
SIMULATION OF REINJECTION AT CERRO PRIETO USING AN IDEALIZED TWO-RESERVOIR MODEL
}

\author{
C. F. Tsang, D. C. Mangold, and M. J. L1ppmann \\ Lawrence Berkeley Laboratory \\ University of California \\ Berkeley, California 94720
}

\section{INTRODUCTION}

Most of the papers published on the hydrodynamic and thermal effects of reinjection in geothermal fields assume a single reservolr with uniform transmissivity and storativity. However, there is evidence that the Cerro Prieto geothermal field is a two-reservoir system and that each reservoir has different hydraulic properties (Abril and Noble, 1979). Because two-reservoir fields have not been adequately studied, we will analyze the thermohydrological response of this kind of geothermal system to varlous alternative schemes of reinjection. We use parameters relevant to the Cerro Prieto system so that the results will be useful in planning future relnjection operations at this fleld.

In our present analysis, we use the LBL integrated finite-difference computer program CCC (Lippmann et al., 1977), which is capable of modeling the complex geological and boundary conditions of a geothermal system. CCC also simulates the major physical factors involved in the movement of the infected waters: (1) forced convective flow between the production and injection areas; (2) heat exchange among injected water, rock matrix, and native waters; (3) denstty-buoyancy effects; and (4) Influence of temperature-dependent $v$ iscosity on fluid flow. The problems associated with the chemistry of the fluids and the porous media--such as injectibility of the wells, injected/native groundwater compatibility, and water-rock interactions--will not be covered here. These matters are addressed in a number of other papers at this symposium.

Instead, we show the results of computations for the response of a two-reservolr geothermal system to injection at various depths and posttions within the field. The influence of differences in thermal, hydraulic, and geometric properties between the reservoirs are discussed. The results indicate that 1 is possible to stabilize or increase reservotr pressures and maintain production temperature in a two-reservolr geothermal field by using an approprlate fluid reinjection scheme.

\section{REINJECTION MODELING}

In any type of modeling study, we may distinguish two broad categories: special studies and detailed simulations. In the case of reinfection, special studies tnclude optimal infection well patterns and the effects of temperature-dependent properties on the reservolr (Tsang et al., 1979). on the other hand, detalled simulations studies are appropriate only after developing a realistic geologic model of the system including its geometry, physical properties, and boundary and initial conditions.

In this general framework, we address a special study of reinjection operations in a geothermal field. We are concerned with the pecularities of carrying out this type of operation in a system consisting of two separate reservoirs. Efforts are being made to develop a realistic geo$\log 1 \mathrm{c}$ model for the Cerro Prieto field, as shown by a number of papers in this volume. In the future, this model will be useful for simulating the behavior of the field and for exploring different relnjection scenarios. By employing a simpler, 1dealized model in this paper, we can begin to determine the best strategles for reinjection so that they can be tested later in more realistic simulations.

\section{TWO-RESERVOIR SYSTEMS}

\section{Model without Intervening Layer}

When there is no intervening layer and no difference in properties between the two reservoirs, the injection of cold water corresponds to the case of a well partially penetrating the geothermal reservoir. Figure 1 shows three cases taken from an earlier study (Lippmann et al., 1977): (A) injecting $100^{\circ} \mathrm{C}$ water into a $250^{\circ} \mathrm{C}$ aquifer in the upper part; (B) injecting $100^{\circ} \mathrm{C}$ water in the lower part of the reservoir; and (c) Injecting beneath a relatively less permeable lens. In all three cases the effect of the lower density of the warmer waters (buoyancy) can be seen; there is a noticeable dispersion of the cold temperature fronts, even when the injected water is restricted for some distance by a lens in the aquifer (case $C$ ). These results will be useful later when considering the behavior of the system in which a continuous layer separates these reservoirs.

\section{Single Well Mode1}

Figure 2 shows a simplified radially symmetric two-reservolr model used for this case, with its initial temperature distribution. The reservoir hydraulic and thermal properties are displayed in Table 1. These data are all taken from an earlier simulation study of Cerro Prieto (Lippmann et al., 1979). Note from the table that the permeability in the lower aquifer is $80 \mathrm{md}$ while in the upper aquifer it is $50 \mathrm{md}$. The intervening layer has a permeability of $0.5 \mathrm{md}$, which is two orders of magnitude smaller than in the upper reservoir, but still not negligible. For simplicity, we 

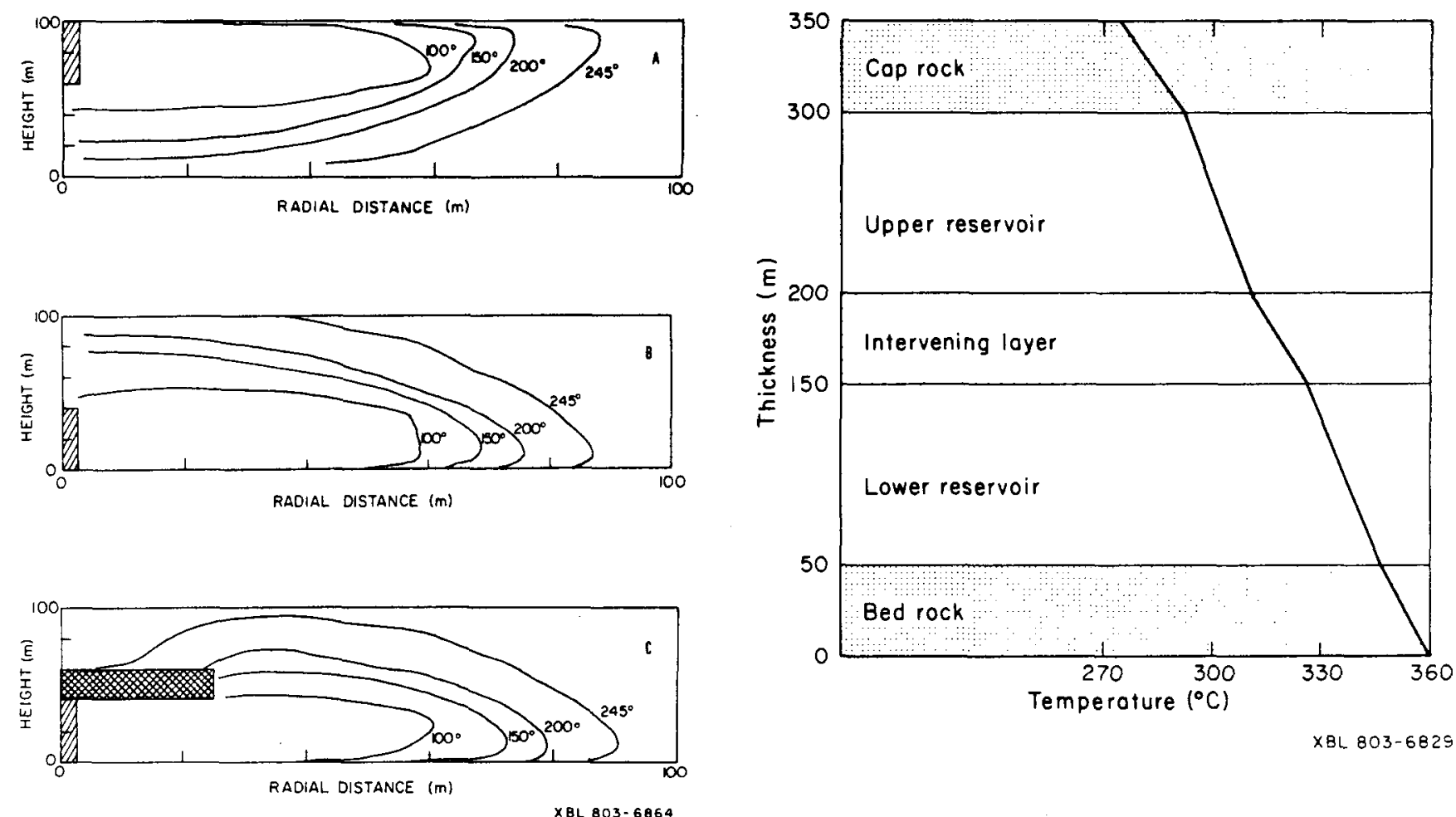

Figure 1. Temperature distribution in the reservoir for the partial penetration case: $A$, injection at the top; $B$, injection at the bottom; and $C$, Injection below a lens of low permeablity material.

Figure 2. Cross section of the two-reservoir model used and 1 ts inftial temperature profile.

TABLE 1. MATERIAL PROPERTIES USED IN THE SINGLE-WELL AND DOUBLET SIMULATIONS

\begin{tabular}{|c|c|c|c|c|}
\hline Property & $\begin{array}{c}\text { Lower } \\
\text { reservolr }\end{array}$ & $\begin{array}{l}\text { Interventing } \\
\text { layer }\end{array}$ & $\begin{array}{l}\text { Upper } \\
\text { reservoir }\end{array}$ & $\begin{array}{l}\text { Bedrock/ } \\
\text { Caprock }\end{array}$ \\
\hline $\begin{array}{l}\text { Intrinsic } \\
\text { permeability } \\
\text { (md) }\end{array}$ & 80 & 0.5 & 50 & 0.005 \\
\hline Porosity & 0.22 & 0.40 & 0.20 & 0.40 \\
\hline $\begin{array}{l}\text { Specific } \\
\text { storage }\left(\mathrm{m}^{-1}\right)\end{array}$ & $10^{-4}$ & $1.6 \times 10^{-3}$ & $10^{-4}$ & $1.6 \times 10^{-3}$ \\
\hline $\begin{array}{l}\text { Thermal } \\
\text { conductivity } \\
\left(\mathrm{cal} / \mathrm{sec}^{\cdot} \mathrm{cm}^{\circ} \mathrm{C}\right)\end{array}$ & $10 \times 10^{-3}$ & $7.5 \times 10^{-3}$ & $10 \times 10^{-3}$ & $6.0 \times 10^{-3}$ \\
\hline $\begin{array}{l}\text { Heat } \\
\text { capacity } \\
\left(\text { cal } / g^{\circ} \mathrm{C}\right)\end{array}$ & 0.250 & 0.230 & 0.250 & 0.230 \\
\hline
\end{tabular}


assume the aquifers are uniformly $100 \mathrm{~m}$ thick and the intervening layer is $50 \mathrm{~m}$ thick. In the mesh there are $38 \mathrm{rad} 1 \mathrm{al}$ steps from the well to the boundary $2.3 \mathrm{~km}$ away; for seven layers (including caprock and bedrock) this means there are 278 elements employed.

Pressure effects (production only). In this serfes of simulations, a constant production rate of $1000 \mathrm{~m}^{3} / \mathrm{hr}$ is assumed (approximately $40 \%$ of the 1978 production rate at Cerro Prieto). The injection rate is at $500 \mathrm{~m}^{3} / \mathrm{hr}$, one-half of the production rate. The three different boundary conditions employed to study pressure effects during production are shown in Figure 3.

The open boundary case corresponds to an aquifer of large radial extent, with a constant potential boundary simulating "full" recharge conditions $2.3 \mathrm{~km}$ awa from the well. The semiopen boundary case had a leaky flow barrier at the same distance to simulate "partial" recharge. The closed boundary case was used as a limiting case, with no recharge through the barrier. The letters $A, B$ and $C$ on the open boundary case are the points where temperature and pressure were determined as the upper aquifer was produced. A is near the well in the upper aquifer and $B$ and $C$ are 100 m away from the well in the upper and lower aquifers, respectively.
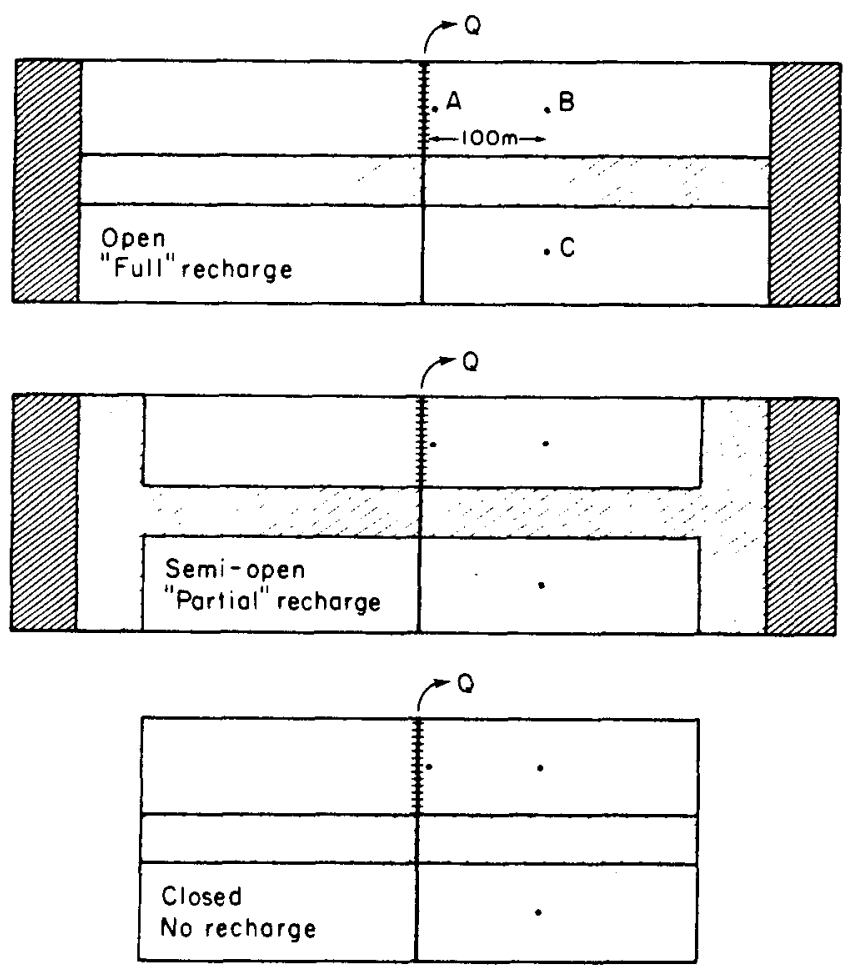

XEL BO3-6830

Figure 3. Sketch of the open, sem1-open, and closed systems used in the simulation of production from a single well. Darkest areas are the constant pressure and temperature boundaries.
TABLE 2. PRESSURE DRAWNDOWNS FOR THE SINGLE WELL PRODUCTION SIMULATIONS

\begin{tabular}{|c|c|c|}
\hline Case & $\begin{array}{r}\text { Pressure } \\
1 \text { to } 5 \text { yrs }\end{array}$ & $\begin{array}{c}\text { drawdowns (psi) } \\
1 \text { to } 10 \mathrm{yrs}\end{array}$ \\
\hline \multicolumn{3}{|l|}{ At Point A } \\
\hline Open & 36 & 40 \\
\hline Semi-open & 38 & 61 \\
\hline Closed & 39 & 64 \\
\hline \multicolumn{3}{|l|}{ At Point $B$} \\
\hline Open & 36 & 40 \\
\hline Semi-open & 38 & 61 \\
\hline Closed & 39 & 64 \\
\hline \multicolumn{3}{|l|}{ At Point C } \\
\hline Open & 32 & 36 \\
\hline Semi-open & 33 & 58 \\
\hline Closed & 35 & 61 \\
\hline
\end{tabular}

Table 2 gives the results of the simulations for 5 and 10 years of production. In comparing pressure reductions for the upper and lower aquifers at elther 5 or 10 years, the results show maximum differences of only $13 \%$ after 5 years, and $10 \%$ after 10 years. This demonstrates considerable hydraulfc communication through the Intervening layer. The results also show the effect of boundary conditions: the open boundary case always has signiflcantly less drawdown after 10 years due to the "full" recharge condition. There is a slightly smaller drawdown due to the "partial" recharge condition for the semi-open boundary case compared with the closed boundary case. The differences among the boundary conditions are not so apparent at 5 years as at 10 years, however.

Temperature effects (infection). Figures 4 and 5 show the temperature fronts after injection of $150^{\circ} \mathrm{C}$ water into the upper aquifer for 3 and 10 years, respectively. Here we assumed an open boundary or "full" recharge condition. Af ter 3 years there is some dispersion of the thermal front at the top of the upper aquifer, but little effect in the intervening layer. However, after 10 years the thermal fronts begin to penetrate through the intervening layer into the lower aquifer. This is partly due to the downward flow of the higher density infected cold water.

Figures 6 and 7 show the temperature fronts in the lower aquifer after 3 and 10 years. of injection, respectively. Again, there is some dispersion of the thermal front within the aquifer, but little effect on the intervening layer. This is encouraging, because it shows that thermal fronts do not easily migrate through the interventing layer.

The boxes below the thermal front diagrams in Figures 4 through 7 indicate pressure changes in 
Injection into upper oquifer ofter 3 yeors

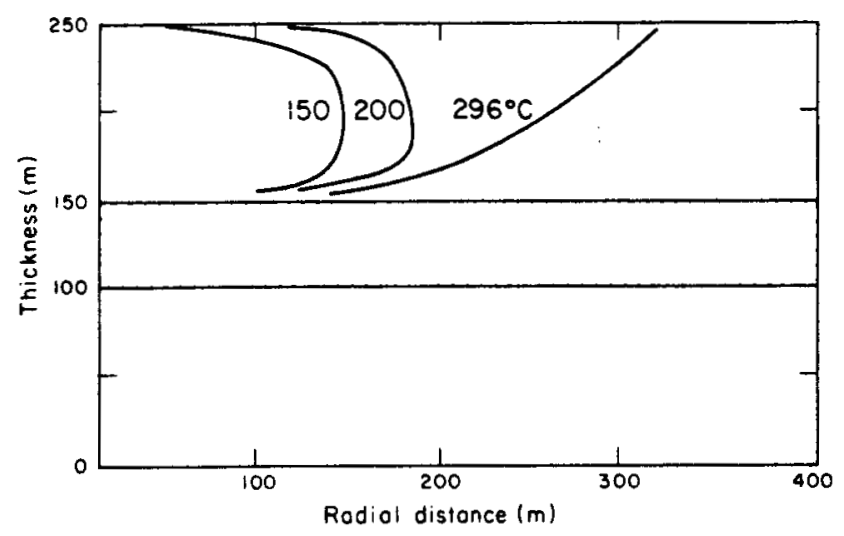

Pressure increose (psi) measured of

\begin{tabular}{|c|cc|}
\hline Aquifer & $500 \mathrm{~m}$ & $1000 \mathrm{~m}$ \\
\hline Upper & 42 & 10 \\
Lower & 22 & 14 \\
\hline
\end{tabular}

$X 8 L 803-683$

Figure 4. Isotherms and pressure changes slmulated for 3 years of single-well infection into the upper reservoir.

Injection into lower aquifer ofter 3 years

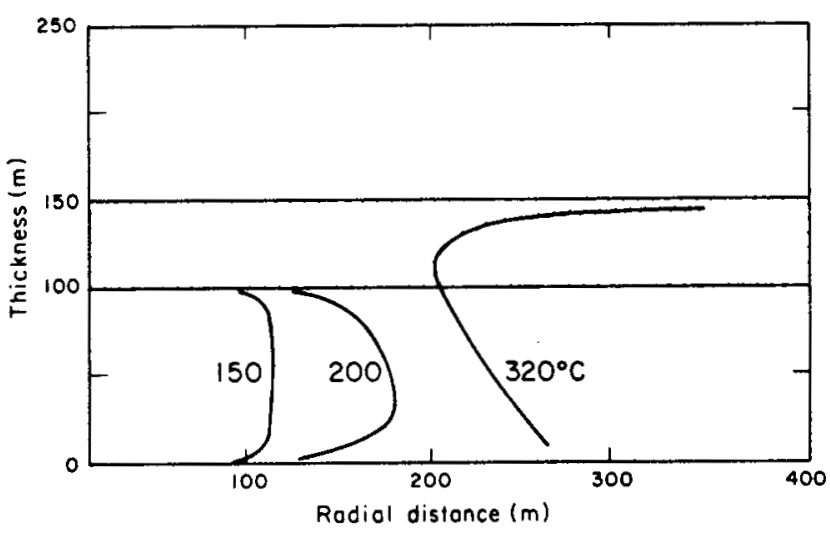

Pressure increase (psi) measured of

\begin{tabular}{|c|cc|}
\hline Aquifer & $500 \mathrm{~m}$ & $1000 \mathrm{~m}$ \\
\hline Upper & 7 & 1 \\
Lower & 45 & 22 \\
\hline
\end{tabular}

$\times 8 L 003-6834$

Figure 6. Isotherms and pressure changes slmulated for 3 years of single-well injection into the lower regervolr.
Injection into upper oquifer ofter 10 years

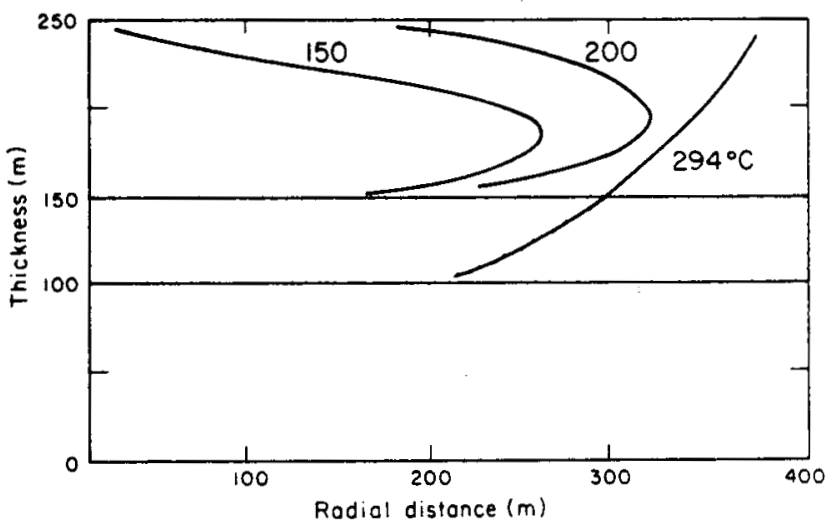

Pressure increose (psi) meosured ot

\begin{tabular}{|c|cc|}
\hline Aquifer & $500 \mathrm{~m}$ & $1000 \mathrm{~m}$ \\
\hline Upper & 54 & 19 \\
Lower & 33 & 22 \\
\hline
\end{tabular}

$x e=8 \div 3 \cdot 6 \varepsilon^{3}$

Figure 5. Isotherms and pressure changes simulated for 10 years of single-well injection into the upper reservoir.

Injection into lower oquifer ofter 10 years

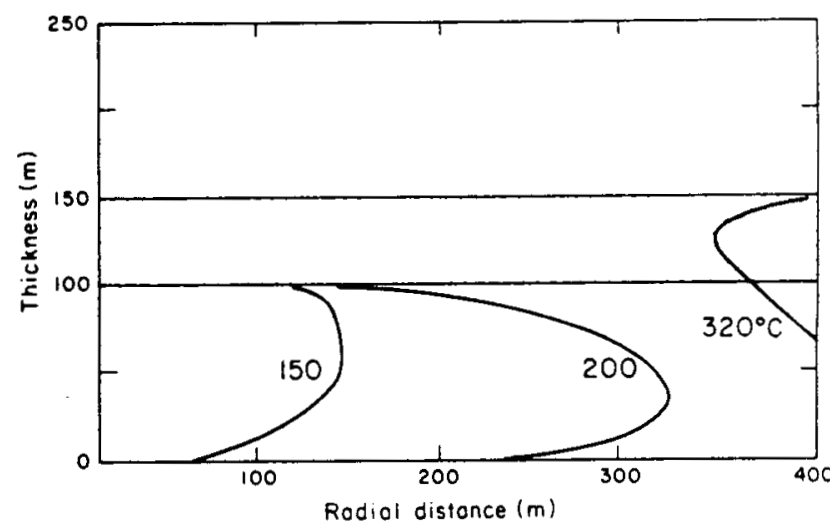

Pressure increase ( $p$ si) measured at

\begin{tabular}{|c|cc|}
\hline Aquifer & $500 \mathrm{~m}$ & $1000 \mathrm{~m}$ \\
\hline Upper & 16 & 9 \\
Lower & 54 & 28 \\
\hline
\end{tabular}

$X B L 603-6835$

Figure 7. Isotherms and pressure changes simulated for 10 years of single-well infection into the lower reservolr. 
the upper and lower aquifers, respectively, at radial distances of $500 \mathrm{~m}$ and $1000 \mathrm{~m}$. These pressures agree with the results of the production tests mentloned above. Desplte the much lower permeability of the intervening layer, pressures are readily transmitted through it from the injected reservoir to the other reservolr over the 3- to 10-year time span. This ind 1cates that reinfection may be useful for maintaining overall reservoir pressures, even through an intervening layer that inhibits thermal fronts, thereby prolonging the useful life of a geothermal fleld.

\section{Doublet Model}

As a further development in modeling reinjection, we simulated the slightly more realistic case of a simultaneous system of production and injection. Figure 8 illustrates the mesh for a two-layer doublet system, which is produced from the upper reservoir at the rate of $2000 \mathrm{~m}^{3} / \mathrm{hr}$ and is infected into either the upper or lower reservolr with $150^{\circ} \mathrm{C}$ water at the rate of $1000 \mathrm{~m}^{3} / \mathrm{hr}$. The three-dimensional mesh makes use of symmetry along the line connecting the production and injection wells, but otherwise it is similar to the single-well model, with the same seven layers, thickness and reservolr properties. The simulated area is $4 \mathrm{~km}$ long by $1 \mathrm{~km}$ wide at the surface, with a $2 \mathrm{~km}$ spacing between production and injection wells, surrounded by a closed boundary. There are 828 elements in the mesh.

The outcome of the simulation at 10 years is displayed in Figures 9 and 10 for infection into the upper and lower reservolrs, respectively. The upper panel shows the temperature fronts for the upper reservolr, the middle one $1 \mathrm{~s}$ a crosssection view wh the intervening layer shaded, and the lower panel shows the temperature fronts for the lower reservolr. (Recall that the upper and lower reservolrs are at different temperatures initially.) The results are similar to the single-

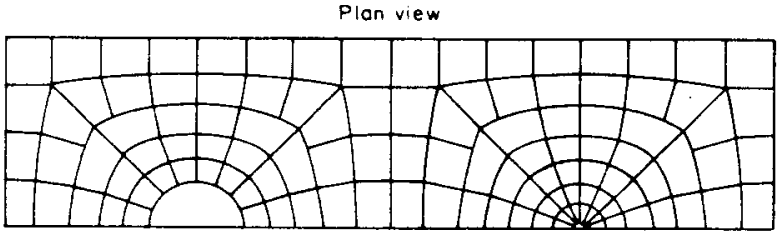

$2 \mathrm{~km} \longrightarrow$

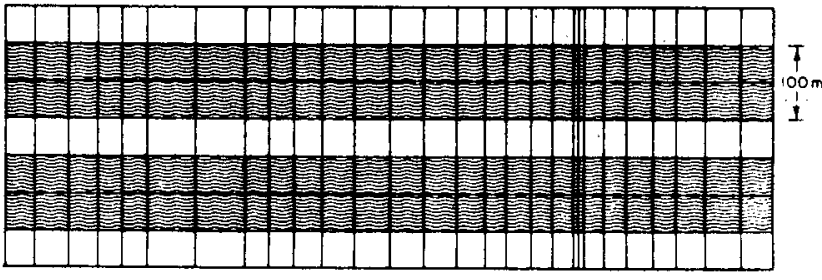

Cross section view

X8L $803-6844$

Figure 8. Plan and cross section views of the doublet mesh.

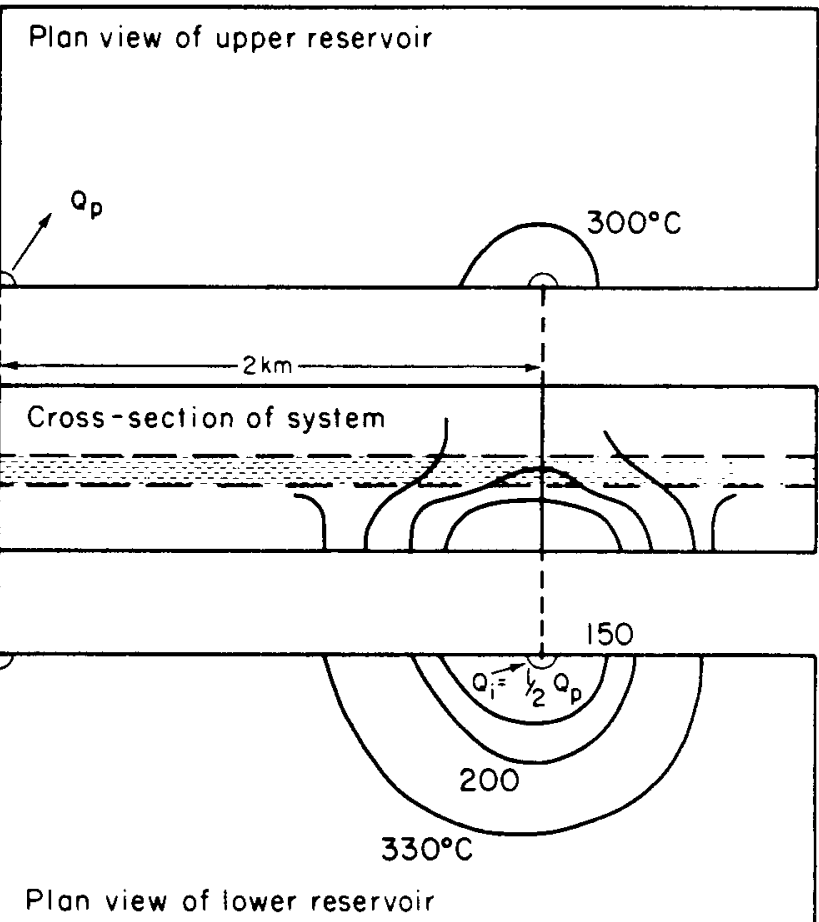

$X B L 803-6828$

Figure 9. Isotherms simulated for 10 years of doublet injection into the upper reservoir.

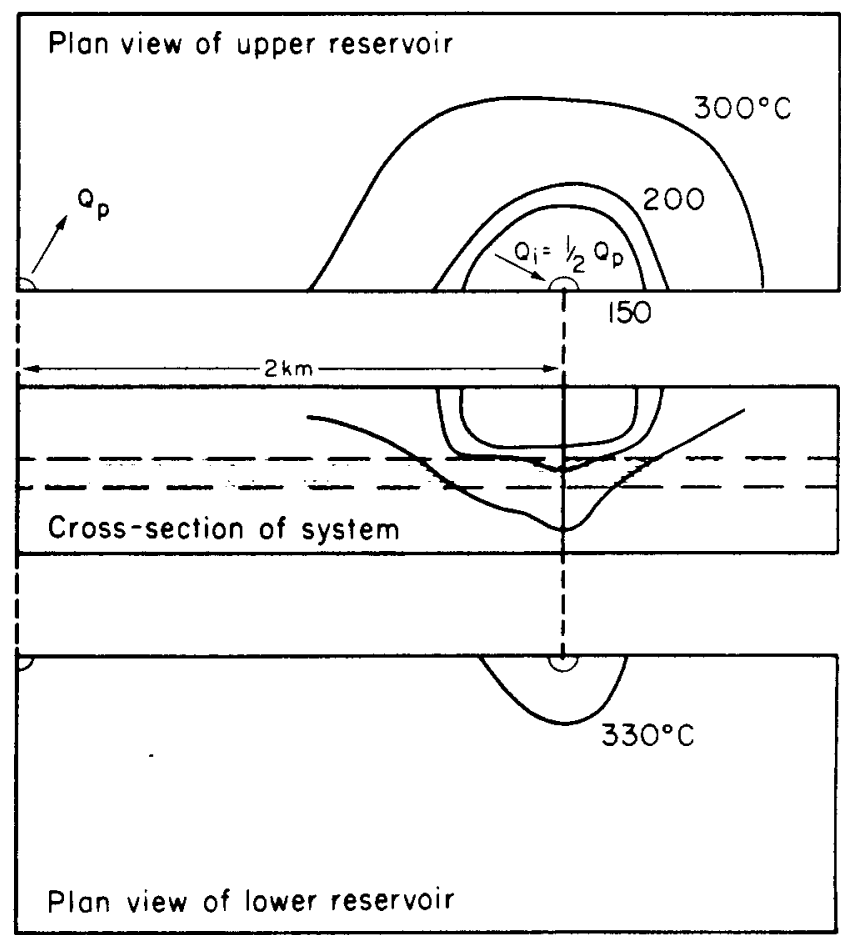

$X B \perp 803-6826$

Figure 10. Isotherms simulated for 10 vears of doublet injection into the lower reservoir. 
well case. Due to its greater density, the colder water, which has been infected into the upper reservoir, penetrates the intervening layer and cools the lower reservolr as before. Injection into the lower reservoir has almost no effect on the upper reservoir, even af ter 10 years, although the thermal front has penetrated into the intervening layer. These results conf1rm that infection into the lower reservolr localizes thermal effects to that reservoir for a long time.

A further case of injection into the lower reservoir was sun with the permeability of the intervening layer increased by one order of magnitude to $5 \mathrm{md}$. The results are shown in Figure 11 for a 10-year simulation. The thermal fronts have spread into the upper aquifer more than in the previous case (Fig. 10), but the effects are still limited to a regton that is within $0.37 \mathrm{~km}$ of the infection well in the upper aquifer, compared with $0.30 \mathrm{~km}$ for the same case with the lower permeability.

The pressure response is given in Table 3 . Pressures are shown there as the differences between the pressure changes resulting from simultaneous production and infection $\left(\Delta P_{1}, p\right)$, and those due to production only $\left(\Delta P_{p}\right)$. The results indicate that the overall increase in pressure from injection is on the order of $100 \mathrm{ps} 1$ at $1 \mathrm{~km}$ from the production well. Again, as in the single-well model, there appears to be very good pressure communication through the intervening layer, because the reservolrs without

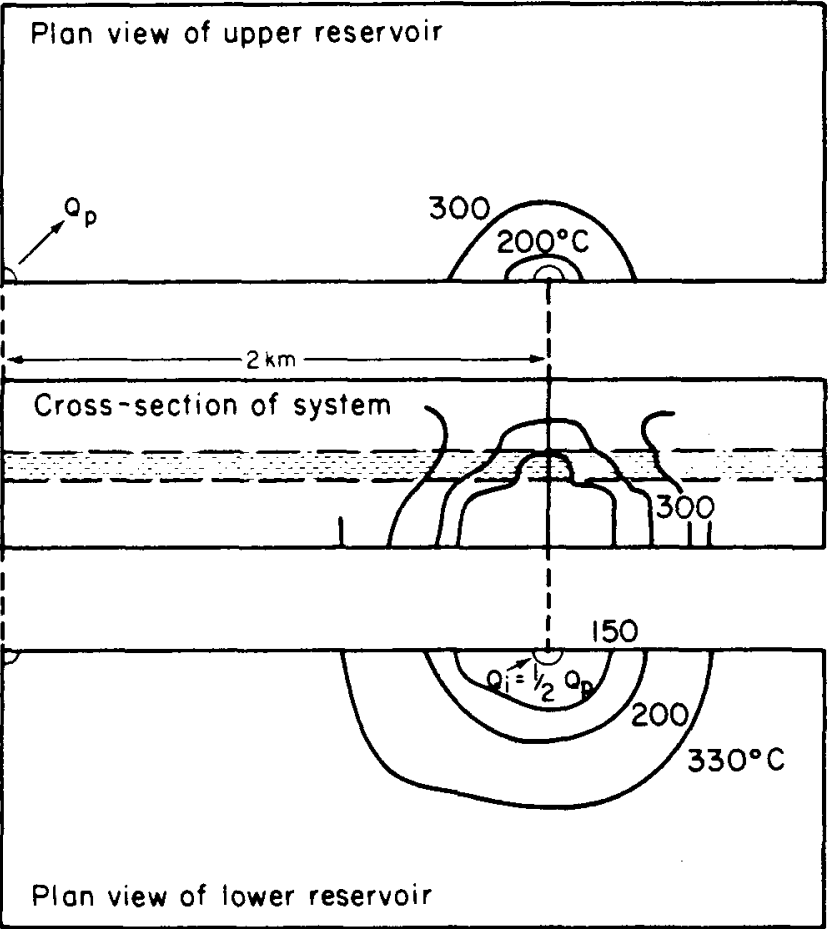

XBL 803-6827

Figure 11. Isotherms simulated for 10 years of doublet injection into the lower reservoir (permeability of intervening layer is 5 md).
TABLE 3. PRESSURE CHANGES FOR DOUBLET INJECTION SIMULATIONS AFTER 10 YEARS ${ }^{\star}$

\begin{tabular}{lcccc} 
& \multicolumn{2}{c}{$\begin{array}{c}\text { At production } \\
\text { well }\end{array}$} & \multicolumn{2}{c}{$\begin{array}{c}1 \mathrm{~km} \text { from } \\
\text { prod. well }\end{array}$} \\
& $\begin{array}{c}\text { Upper Lower } \\
\text { Reservolr }\end{array}$ & $\begin{array}{c}\text { Upper Lower } \\
\text { Reservoir }\end{array}$ \\
\hline Upper injection & 78 & 80 & 132 & 120 \\
Lower Injection & 81 & 88 & 120 & 138 \\
$\begin{array}{c}\text { Lower injection } \\
\text { (intervening layer permeability }=5 \mathrm{md})\end{array}$ & 226 & -3 & 148 & 116 \\
\hline
\end{tabular}

${ }^{*} \Delta \mathrm{P}_{1, p}-\Delta \mathrm{P}_{\mathrm{p}}$ (psi), where $\Delta \mathrm{P}_{i, p}=$ change in pressure in the case of simultaneous injection and production; and $\Delta \mathrm{P}_{\mathrm{p}}=$ change in pressure in the case of production only.

Infection have pressures that are within 10 to $15 \%$ of those of reservolis with injection. The lower pressure at the producing well for the upper infection case appears to be caused by the thernal effects described below.

The pressures for the higher permeability case for the intervening layer are much higher near the production well. If the same "production only" pressures are used for the pressure differences in this case, the results show an increase of 145 ps 1 in the production area (Table 3 , last line).

The pressure response for the upper injection case over the 10-year perlod is shown in Figure 1? (with the usual 0.5 md for the permeability of the intervening layer). The pressure profile between the production area and the injection well displays a transition region between the injected $150^{\circ} \mathrm{C}$ water and the surround ing $302^{\circ} \mathrm{C}$ water. In this region, the viscosity changes significantly due to fluid temperature differences (a ratio of nearly $2: 1$ ), producing a moving thermal barrier which $c$ an be responsible for larger-thanusual pressure declines in well test analysis (Mangold et al., 1979). Figure 13 suggests the Influence of this effect on pressure response in a comparison between the cases of upper and lower injection. After 10 years of upper injection, the production well area actually has a lower pressure than the lower injection case, probably due to the thermally produced viscosity barrler in the upper aquifer. For the lower injection case, the pressures in the upper aquifer are not as affected by such a barrier since it is restricted to the lower aquifer. Such results ind fcate that a combination of viscosity and buoyancy effects are needed in order to ad equately describe the physical processes of reinjection, especially in a two-reservolr system. These matters will be the subject of a further investigation.

Thus the doublet model further confirms that in a more realistic model of a two-reservoir system, reinfection will be useful in maintaining reservoir pressure while restricting the thermal front to the neighborhood of the injection area. 


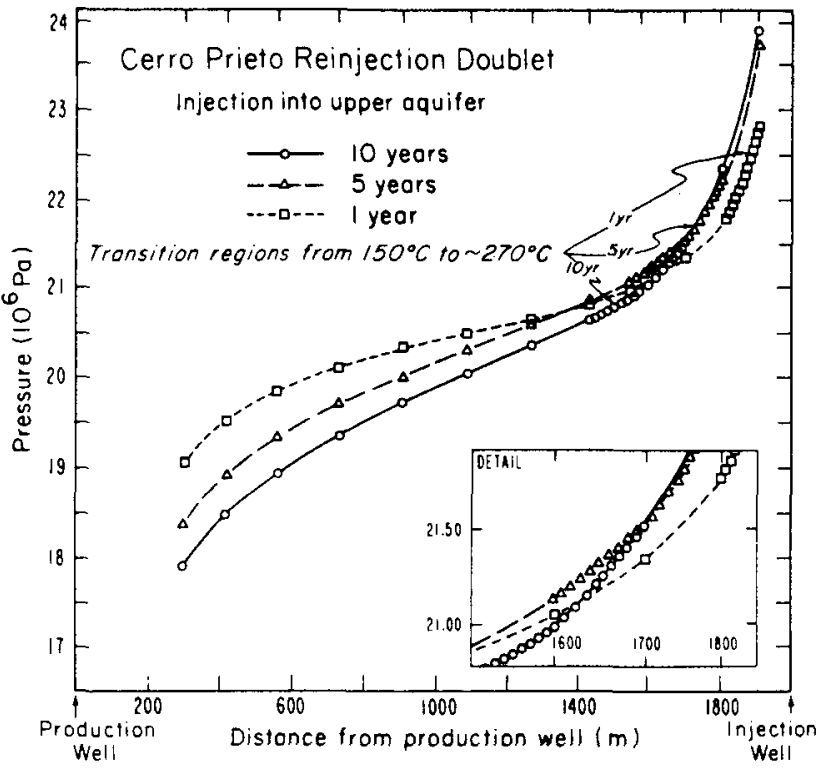

$\times B L 803-6832$

Figure 12. Radial pressure distribution simulated for 1,5 , and 10 years of doublet injection into the upper reservoir, showing the transition region between hot and cold waters.

\section{CONCLUSION"}

In this paper we have introduced an 1dealized two-reservoir model to explore some of the effects of reinjection in a geothermal field. For both the single-well model and the doublet model, the results indicate that reservoir pressures will be adequately maintalned even when an intervening layer of low permeability is present. The same interventing layer may nevertheless be an effective barrier to the movement of cold fronts, due to the effect of gravity and viscosity on the flow of denser colder waters. This shows promise for developing reinjection strategies that can be tested on more detalled simulation models for specific sites such as the Cerro Prieto field.

In further research we hope to conduct a sensitivity analysis on some of the main parameters used in this study, especially permeability. Clearly, there is also a need to study the flow of the colder water toward the production well for a longer period of time than 10 years. Simulations of permeability anisotropy and optimum well spacing for injection may have to walt until detalled geological models become avallable. Idealized models like the ones employed in this study, however, are useful for suggesting practical reinjection operation strategies for optimizing the development of geothermal energy resources.
Cerro Prieto Reinjection Doublet

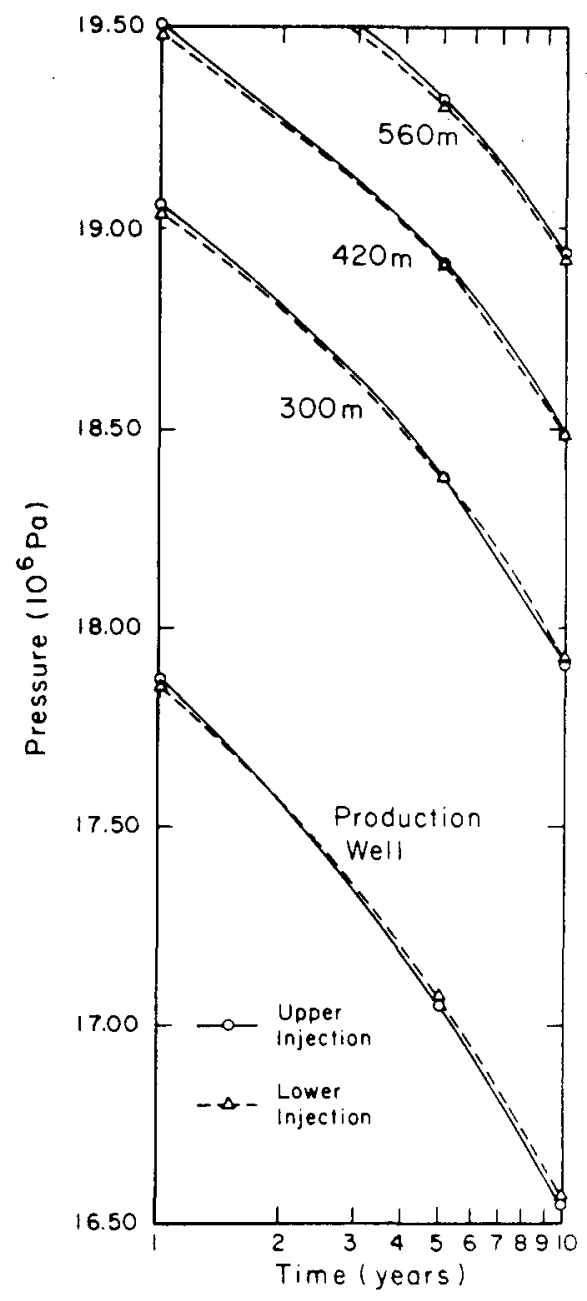

$x B-803-583 \epsilon$

Figure 13. Pressure changes near the production area simulated for 1,5 , and 10 years of doublet injection into the upper and lower reservoirs.

\section{ACKNOWLEDGMENTS}

Work perforned for the U. S. Department of Energy, Division of Geothermal Energy, under contract $\mathrm{W}-7405-\mathrm{ENG}-48$.

\section{REFERENCES CITED}

Abril G., A., and Noble, J. E., 1979, Geophysical well-log correlations along various cross sections of the Cerro Prleto geothermal fleld, in Proceedings, First Symposium on the Cerro Prieto Geothermal Field, Baja California, Mextco, September 1978: Berkeley, Lawrence Berkeley Laboratory, LBL-7098, p. 41-48. 
L1ppmann, M. J., Bodvarsson, G. S., W1 therspoon, P. A., and Rivera R., J., 1979, Preliminary simulation studies related to the Cerro Prie to field, in Proceedings, First Symposium on the Cerro Prieto Geothermal Field, Baja California, Mexico, September 1978: Berkeley, Lawrence Berkeley Laboratory, LBL-7098, p. 375-387.

L1ppmann, M. J., Tsang, C. F., and Wt therspoon, P. A., 1977, Analys1s of the response of geothermal reservoirs under injection and production procedures: Dallas, Society of Petroleum Engineers, SPE-6537.
Mangold, D. C., Tsang, C. F., Lippmann, M. J., and Witherspoon, P. A., 1979, A study of thermal effects in well test analysis: Dallas, Soclety of Petroleum Engineers, SPE-8232.

Tsang, C. F., Bodvarsson, G. S., IJppmann, M. J., and Rivera R., J., 1979, Some aspects of the response of geothermal reservotrs to brine reinjection with application to the Cerro Prieto field, in Proceedings, First Symposium on the Cerro Prieto Geothermal Fleld, Baja California, Mexico, September 1978: Berkeley, Lawrence Berkeley Laboratory, LBL-7098, p. 396-403. 
This report was done with support from the Department of Energy. Any conclusions or opinions expressed in this report represent solely those of the author(s) and not necessarily those of The Regents of the University of California, the Lawrence Berkeley Laboratory or the Department of Energy.

Reference to a company or product name does not imply approval or recommendation of the product by the University of California or the U.S. Department of Energy to the exclusion of others that may be suitable. 
TECHNICAL INFORMATION DEPARTMENT LAWRENCE BERKELEY LABORATORY UNIVERSITY OF CALIFORNIA BERKELEY, CALIFORNIA 94720 